\title{
"It Makes the Whole Learning Experience Better": Student Feedback on the Use of the Interactive Whiteboard in Learning Chinese at Tertiary Level
}

\author{
Hui Ling Xu \\ Department of International Studies, Macquarie University \\ Balaclava Road, North Ryde, Sydney, Australia \\ Tel: 61-2-9850-1005Ｅ-mail: huiling.xu@mq.edu.au \\ Robyn Moloney \\ Department of Education, Macquarie University \\ Balaclava Road, North Ryde, Sydney, Australia
}

Tel: 61-2-9850-8605 E-mail: robyn.moloney@mq.edu.au

Received: September 8, 2011

Accepted: October 11, $2011 \quad$ Published: November 1, 2011

doi:10.5539/ass.v7n11p20

URL: http://dx.doi.org/10.5539/ass.v7n11p20

\begin{abstract}
The widespread use of interactive whiteboards (IWB) in primary and secondary schools has been well documented, yet there is to date only limited attention to use in tertiary institutions. Macquarie University has installed this technology in many of its teaching spaces in the past few years. This paper reports a case study undertaken in the university's undergraduate Chinese beginner course, which began to use IWB learning activities in 2009 .

Our study was undertaken to obtain students' perceptions of the IWB pedagogy in Chinese language acquisition in general and in particular, of the effectiveness of IWB in the retention of Chinese characters. To many students whose first language is non-logographic, the recognition and retention of characters are the most difficult tasks in learning Chinese.

Our findings indicate that the IWB's affordance to create a variety of visual activities has impacted, most saliently, the retention of characters and syntactical elements. Students also report that the IWB has enhanced the learning experience, reflected in increased motivation and engagement through interaction with this technology. The tertiary students reveal particular learning priorities, in appreciating interaction, intellectual demand and participation, as components of effective learning. The feedback process itself proved to be useful in facilitating critical awareness in both teacher and students, of teaching strategies and learning respectively.
\end{abstract}

Keywords: Feedback, Interactive whiteboard, Language learning, Pedagogy, Chinese language, Tertiary teaching learning

\section{Introduction}

Since the introduction of IWBs in educational settings more than one and a half decades ago, there has been robust research carried out in the UK, US, Canada, and more recently Australia. This research has investigated the IWB's potential (Schmid, 2006, 2008), its impact (Glover \& Miller, 2001; Smith, Hardman \& Higgins, 2006; Kennewell, Tanner, Jones \& Beauchamp, 2008), and has captured teachers' and students' perceptions of IWB engendered activities (Xu \& Moloney, 2011; Orr, 2008; Schroeder, 2007; White, 2007; Wall, Higgins \& Smith, 2005) (for summaries of literature see Glover, Miller, Averis \& Door, 2005; Digregorio \& Sobel-Lojeski, 2009). Empirical research efforts such as these indicate the increasing presence and popularity of this educational technology, as part of an increasing government and institutional commitment to the use of technology to enhance student learning and to encourage innovation in teaching. Such is the case at Macquarie University which progressively installed the IWBs in its classrooms since 2008. The use of IWB is still limited in tertiary 
sectors and there has thus been limited research in the tertiary context into the applications of IWB. This study investigated the application of the IWB technology in tertiary language teaching and learning and used student feedback to assess whether the IWB is an effective tool in the classroom learning environment. As the first author teaches Chinese studies, the project focused on the Chinese language. Furthermore, the researchers believed that the beginner level Chinese course should be the pedagogical research focus, as student success at this level is both difficult in itself, and critical to sustaining motivated study into higher years.

An earlier study observed IWB use in language learning in secondary schools (Xu \& Moloney, 2011). Subsequently, IWB activities were developed and used in the undergraduate beginner Chinese course at Macquarie University from the second semester of 2009. Informal feedback from students was sought and progressive changes and modifications made to the teacher's IWB teaching materials. After three semesters' use of IWB, we believed it was timely to conduct a formal evaluation survey in order to gauge students' feedback in terms of their attitude towards the application of this new technology and their perception of its effectiveness in enhancing their learning experience. This paper reports our findings from both quantitative and qualitative data. Before we proceed to the discussion of the data, however, we review some relevant literature.

\section{Literature Review}

This review examines literature informing the component issues of this study, that is, students' experience of IWB learning across the curriculum and in languages in particular, and the role of accessing student feedback for teacher reflection in progressive development of effective pedagogy.

The advantages of the IWB can be attributed to its particular features and the learning style they may facilitate. IWBs are primarily large-screen digital convergence facilities, which can bring together digital resources like text, images, audio, video and a wide collection of resources from the web (Betcher \& Lee, 2009, p.8). As a result of these features, relevant studies have reported a number of common benefits associated with the use of this presentation technology, including increased motivation, visual engagement, interaction and participation in class. These features may facilitate an increased capacity to cater for different learning styles, deeper learning, and more efficiency in learning and retention.

A number of studies has shown that the IWB facilitates interaction in learning activities among primary and secondary students across the curriculum (see for example, Asmawi, 2005; Glover \& Miller, 2001 ; Higgins, Beauchamp \& Miller, 2007; Lewin, Somekh \& Steadman, 2008). The study of a science classroom by Hennessy, Deaney, Ruthven \& Winterbottom (2007) highlights the fact that the strength of the IWB lies in its support for shared cognition, especially in the articulation, collective evaluation and reworking of the students' own ideas, and co-construction of new knowledge. In languages, this aligns with the current socio-cultural approach to language pedagogy which highlights acquisition of language as occurring in social interaction (Scarino \& Liddicoat, 2009).

IWB pedagogy has been shown to be aligned with increased student motivation and affect. While an unlimited number of uncontrolled variables and factors can affect student motivation, Weimer (2001) reports a clear link between motivation and learning technologies. Secondary language students report that their anticipation and enjoyment of IWB activities in lesson enhances motivation for the subject (Xu \& Moloney, 2011). Schroeder (2007) also emphasized the value of the affective domain as it focuses on learners' motivations, their attention to and emotional response to learning and the value they attach to learning (p.66). Indeed, these links were reported in Schroeder's study, as it showed that using an IWB in library sessions positively increased students' attention to tasks at hand.

The features of the IWB may be especially suited for some aspects of language learning. For example, the visual aspect of the IWB has been shown to be an important element in active engagement in the learning process by students (Beeland, 2002). Smith, Hardman and Higgins (2006) found also that pupil interest in learning is enhanced because of the particular element of visual surprise, enabled by the many IWB tool options for creating hide-and-reveal activities. In one of our studies, the visual surprise aspect prompting better recall was reported to be a key component of the visual memorization of Chinese characters. Furthermore, the teacher can use the capacity of the board to create visual drilling materials, upload text and audio materials, record student dialogue, present collaborative reading and writing practice exercises, and embed links to authentic cultural materials from relevant websites (Xu \& Moloney, 2011). In a detailed study, Gray, Hagger-Vaughan, Pilkington and Tomkins (2005) found evidence in a number of areas of the effectiveness of the IWB in the teaching of languages. For example, teacher respondents commented that the use of the IWB supported them in encouraging students to practise and recycle recently presented language. Visual effects such as colour-highlighting and animation were felt to be the most important aids in drawing attention to language patterns. The study reported that language 
learner participants felt that the use of the IWB had a positive effect on memorisation skills and writing development. The study concludes that, though teachers initially need extra planning and preparation time, the IWB is a support for good language teaching.

In language learning, many different activities are needed, both to develop a range of different skills (listening, reading, speaking, writing), and to enable frequent varied repetitions and re- exposures of learnt language, in order to build cumulative recall and acquisition. These activities have always included a range of text-based, practical, hands-on, visual, verbal role-play, kinaesthetic activities using objects, flashcards, the overhead projector, games, songs and drama activities. There is an apparent need for ongoing research in developing a similar range of best-practice IWB pedagogy which meets contemporary expectations of good language learning, including the ability to think critically about cultural difference. Scarino and Liddicoat (2009) advise that communication and information technologies are effective in language learning at all levels when they are integrated, enabling teachers and students to access contemporary authentic materials and interactions, facilitating participation in the language, and providing students with personalized learning opportunities. Scarino and Liddicoat (ibid) stress that we can use technology to provide opportunities for students to make choices, to create tasks, to use games, to explore texts, and to engage students in language and culture simulations

Research concerning the special needs of Chinese language learning is limited. However, in a secondary context, Pang $(2008,2009)$ reports evidence that as a result of her IWB pedagogy, students' academic results improved, and that she was able to compact the syllabus and reach learning goals more quickly. Pang's pedagogy reflects the IWB learning goals established by Betcher and Lee (2009). This includes her use of software which enables students to manipulate language, the facilitation of students' ability to engage in life in another context, increased levels of interactivity and student involvement, and the use of interactive voting systems (Betcher \& Lee, ibid). In a related context of teaching a non-Roman script, Tozcu (2008) found that the interactive whiteboard appears to be a useful pedagogical multi-media tool for teaching non-roman scripts such as Hindi and Pashto because the visual presentation as well as interactive tasks and activities shorten the acquisition period, and enable effective student retention and review (Tozcu, ibid., p.158).

Finally, as noted, this study became engaged with the role of feedback itself in teacher and student reflective practice. Teachers have used and appreciated the value of reflective practice to improve teaching and student learning outcomes (McNiff, Lomax \& Whitehead, 2003; Somekh, 1995). Becoming aware of students' learning needs and in particular, the use of feedback to access information about student needs, in teacher reflective practice, is regarded as an important part of teacher development (Loughran, 2002). Teacher development in use of new technologies in language teaching, involves not only shifts in new technical and pedagogical knowledge (Hubbard \& Levy, 2006), but also, importantly, the ability to orient students to new ways of accessing target language learning opportunities (Dornyei \& Ushioda, 2009; Richards \& Farrell, 2005). Furthermore, the process of feedback engages both teacher and students in metacognition as it increases their critical awareness of their own teaching and learning strategies respectively.

\section{The Study}

\subsection{Aims of the study}

A large-scale report on Chinese language education in Australian schools has found that various factors have affected both the retention rate and the achievement of greater proficiency in Chinese (Orton, 2008). The intrinsic difficulty of the Chinese language, such as tones and characters, is found to be a restriction for students of English-speaking backgrounds (p.5). In the tertiary sector, students generally find learning the Chinese language challenging and retention rate is anecdotally not deemed to be satisfactory across universities. To support successful learning of Chinese, Orton (ibid) has recommended a greater use of modern technology to assist in oral, reading and writing competence. In the tertiary sector, great importance has also been attached to the use of educational technology to enhance learning experience. Against this specific background and with IWB having been applied in the teaching and learning of Chinese at Macquarie University, the aims of our study were to use students' feedback to:

1) investigate students' views of the integration of this technology in the learning and teaching process

2) investigate which IWB qualities make the IWB technology most useful and effective in language learning

\subsection{Methodology}

(1) Participants:

The student cohort $(n=44)$ was two classes of first year beginner Chinese students who were in their second 
semester of Chinese study. Their participation in this project was on a volunteer basis. The two researchers are involved in foreign language education: while Hui Ling Xu teaches Chinese studies in the Department of International Studies, Robyn Moloney is a language teacher educator in the School of Education, teaching Language Methodology courses to pre-service teachers.

(2) Data collection:

This project used two data collection tools including both quantitative and qualitative methods. They are described below:

Student survey. A questionnaire was designed and administered to the students at the end of second semester 2010. The questionnaire consisted of 20 statements with a Likert-scale response and a ranking exercise of the importance of various aspects related the IWB (The survey questionnaire is included in Appendix 1).

Focus group interview. In order to capture the students' more personal metacognitive responses to their learning and more analytical reflections, 30-minute focus group interviews were conducted, audio-recorded, transcribed and analysed

The transcripts of interviews with the student groups were thematically and inductively coded by Content Analysis, using coding systems developed by the researchers (Ryan \& Bernard, 2000). A form of methodological triangulation was achieved through the use of the different sources of data, exploring pedagogy and student learning from the different perspectives represented.

In order for the student feedback below to be meaningful in the pedagogical context, a brief description of the IWB learning strategies employed, and their rationale, is offered in the next section.

(3) Description of IWB language learning strategies employed:

This description has been constructed from lesson observation carried out by Author 2. The IWB activities were designed with the objective to help the students acquire the language faster and more effectively, in particular, character recognition and retention. The strategies the teacher has chosen to employ may be assessed against an understanding of what constitutes effective language learning.

Effective language learning is regarded today as involving a number of aspects. Amongst these, social collaboration with more capable others (teachers, peers) who provide assistance (Oxford, 1997) is regarded as important. Social interaction lies at the heart of communicative competence. As learners interact with each other through oral and written discourse, their communicative abilities are enhanced. Douglas Brown (2007) also highlights the importance in good language learning, of cognitive engagement. This includes the issues of learning being meaningful, active, and intrinsically motivated, with a degree of autonomy. Willingness to communicate, self-confidence and risk-taking, and involvement in the cultural context of the language are regarded as important socio-affective aspects of language learning (Douglas Brown, ibid.).

To facilitate effective Chinese learning with the IWB, in consideration of the principles above, the teacher in this study has designed a variety of interactive activities, catering for reading, speaking, and listening, practice of linguistic structures, involving multiple exposures and activities for frequent character recognition and retention. Activities are designed for differentiated practice, from simple single characters to construction of longer lexical units, engaging different language skills sequencing from simple recognition to active production. The language workshops are two hours duration, twice a week, for a 13 week semester.

At the simple reading level, bringing students to the board to participate, the teacher moves around elements on the board to hide and reveal characters, match and connect characters, pictures, pieces of text. The software of the board and her own saved resources equip her to insert many visual and audio elements alongside text elements. The "click and drag" ability of the board enables the rearrangement of text units into correct word order. She uses this also to present a variety of text elements which students arrange to creatively construct their own individual sentences. These reading activities scaffold the language structures which students then use in speaking and writing activities more effectively, in particular, character recognition and retention.

To address listening skills, the teacher uses the audio recording capacity of the board to make a variety of sound files, which may range from a simple element to a complete sentence. Students open and listen to the sound files to match them to their meaning, expressed in a corresponding visual or text element in Chinese characters.

To stimulate speaking practice, she reveals visual elements such as pictures to stimulate construction of speaking interaction, recycling language already established through reading and listening. She uses the board's online capacity to insert links to websites of relevance, which may include online language games in Chinese, or cultural websites of relevance to the topic. 


\section{Findings and Discussion}

\subsection{Quantitative data}

Forty four undergraduate students completed the survey questionnaire. The survey questionnaire consists of two parts. Part one has 20 questions each of which is followed by a five-point Likert scale, with the alternatives labelled from 'Strongly Disagree' (1) to 'Strongly Agree' (5). To avoid the halo effect, several questions were phrased negatively. The anonymous survey data was analysed and the results are presented below in Table 1 (at the end of article).

These questions can be roughly divided into clusters each of which looks at an area of interest to our research objectives. Questions 1-3 focus on the affective aspect: whether IWB helps increase motivation and engagement. As can be seen, the three mean scores are quite high, especially question 3, which has the highest mean score among all of the 20 questions. This is an extremely important finding, confirming other research findings that there is a positive correlation between students' engagement and learning success. Students' full participation is also said to promote higher learner control (Tanner, Jones, Kennewell \& Beauchamp, 2005) and deeper learning (Biggs, 1989, 1999). This finding also indicates that to tertiary students, an innovative approach which engages them more and allows greater participation in the teaching-learning process has great appeal because it departs from what appears to be a traditional mode of instruction in tertiary institutions, which was put by Radloff and Sampson (1988) as "one person talking and the many listening" and that "many students perceive their role as passive listeners and recorders of thelecture content...they write much and understand little" (ibid.:4).

Questions 4-9 direct students' attention to whether the IWB helps in facilitating acquisition of specific skills. A comparison of the mean scores shows that question 8 stands out, with a mean score of 4.21 , which suggests that indeed, the visual and interactive features of the IWB are quite salient and effective in helping the students remember characters. Given that learning characters is generally perceived by students of non-logographic language backgrounds as a challenging task, this finding certainly has positive implications for the continuation of design of teaching activities to assist students in this aspect of learning. But students' feedback on question 9, which received a relatively lower score $(M=3.6)$, shows that as far as writing characters well is concerned, it is not something that can easily be achieved with the IWB, as it requires a great deal of personal effort and practice after class. The second high mean score in this group is question 4, which comes as no surprise because in a logographic language, it is the character which carries the meaning of a word. Therefore, the ability to recognize characters is certainly the key to acquiring vocabulary. In terms of oral and audio proficiencies, IWB was not considered very helpful in the students' views, as indicated by the low mean scores in question 5 and 6 respectively.

Examining the response to questions 10-13, which broadly look at whether the IWB enhances learning experience, it shows that the scores are generally positive, particularly questions 11-13. This confirms findings commonly reported in IWB-use literature. For example, Hodge and Anderson (2007) note that "IWB impact on the nature of resource presentation and on learning processes, potentially affecting the development of thinking skills, encoding and retention of information" (ibid.:272).

Throughout the three semesters when the IWB activities had been incorporated into the beginner Chinese program, students' informal feedback indicated that the IWB does best for learning characters and vocabulary. We therefore included questions 14 and 15 , whose scores further support those of questions 4 and 8 , indicating a consistent view by students in this regard. Furthermore, students also believe that the IWB is good for foreign language teaching. This finding is encouraging given that the vast use of the IWB currently in schools has concentrated on subjects other than foreign language teaching.

The last questions are phrased in the negative with the purpose of determining potential limitations and the students' attitudes towards this educational technology. Results show that the responses to these questions scored quite low, especially question 19 which asked students if the IWB had been used too much, suggesting that the students on the whole embrace this innovative and multimedia-based pedagogy.

Apart from the 20 Likert-scale questions, we included six questions in which we asked the students to rank, in terms of importance, some relevant aspects of the IWB. The results (as six students did not complete these questions, the sample is $n=38$ ), shown in Figures 1 and 2 (the division of the results into two figures is purely for ease of discussion) (Figures are at the end of article), strongly support existing findings in various studies and our own sources of data. In Figure 1, it is clear that to the students, the interactive aspect is the most important, which is consistent with our earlier finding that the IWB promotes engagement and participation, two aspects closely related to interaction. Contrary to our findings in an earlier study in a secondary context, the visual aspect 
and the fun aspect do not rank as high, which means that for higher level learners, it is the engagement in learning, that is, deep learning, that is more important.

Figure 2 summaries the results of the ranking of another three aspects. It can be seen that the effectiveness of the IWB is ranked quite high, with the other two aspects, multimedia and moderntech, obtained relatively similar frequencies. What we can infer from this is that perhaps while secondary students are more accustomed to the use of educational technology and therefore are no longer overwhelmed by the novelty of using technology itself, for the tertiary sector, the IWB may still possess that novelty 'wow' factor. Thus, to incorporate an e-teaching component in tertiary teaching and learning process is therefore viewed as important and effective.

\subsection{Qualitative data}

The student interviews were transcribed and thematic analysis of the transcript was carried out (Ryan \& Bernard, 2000). The identified themes have a degree of overlap, and student utterances in one theme may imply intended connection with another theme, even though not articulated. For example, activities featuring sentence structures are inevitably linked to recognition of characters.

Although the sample of this study is small, some observations may be made from the analysis of the qualitative data. Findings need to be understood in relation to the tertiary teaching context, that is, students' expectations of learning experience in the tertiary teaching environment.

Table 2 (at the end of article) demonstrates that a recurring dominant theme in student discussion was their perception of the effectiveness of intellectual stimulation afforded by the IWB activities:

They are like games, but some people learn from games, and games help keep your brain working...the end result is that it helps you sort of think of new ways of what you learn. (student 9)

Everybody is watching and thinking and comparing in their mind their answers to the student's answers, the activities set them thinking. (student 7)

It prevents you from sleeping. (student 3 )

It doesn't, you know, make our minds turn off. (student 6)

Glover and Miller (2002) found that getting students to come up to touch the board is alone a valuable feature as it motivates students to come to the front of the classroom and speak to the whole class. Our students also prioritized motivation arising from the physical movement of getting out of their seats to come to the board. Students indicated that this spatial issue of working in front of peers also represents a degree of public exposure of their competence. They perceive this as positive, motivating them to prepare the work, in order not to embarrass themselves:

Everybody is watching. (student 7)

You don't want to go up there ... and you don't know anything. (student 2)

Interaction through language activities was mentioned by 5 of 11 participants. We have described in the previous section the variety of IWB activities which require students to interact with the board, and with each other:

The interactivity, physical interaction, and moving the words around, which is hands-on interactive, even though one student is doing it, it sort of helps the whole class. (student 7)

I am a hands-on person, so I like to go up to do the exercise because it gives you the control, and by doing this, it stuck to my memory and became my knowledge. (student 4)

Being like for everyone to interact with each other and actually have to guess and play it together as a whole class. (student 9)

The visual aspect of the board was mentioned by 5 of 11 participants, but may have been implicit in other comments:

The IWB is a visual helping aid, we can still study the textbook, but we cannot remember the characters as well, but with the IWB you look at them all the time and they stick in your memory. (student 2)

It adds an element of surprise, and you cant prepare beforehand. (student 5)

She has like pictures to match up with words which does help a lot, 'cause its just reinforcing the characters and what they mean. (student 8)

The visual element is also important in engagement with cultural aspects of China:

When we were learning about Hainan Island, we only learned from textbook how beautiful it is, but with the 
virtual pictures, we can see how beautiful it is. (student1)

The teacher in this study, like the teacher in the teacher in the secondary school study (Xu \& Moloney, 2011), has not as yet explored the potential of the IWB for intercultural language learning. This is currently prioritized in language pedagogy at all levels (Kramsch, 1993), and involves student engagement with explicit reflection on difference and similarity between cultures and languages (Scarino \& Liddicoat, 2009). This is an area for future development and research in IWB language pedagogy.

We have noted that the achievement of more effective character retention is the principal goal of the teacher, in her use of the IWB. Students perceive the IWB to be effective in this specific challenge. Even though the percentage of students mentioning this theme is low, the ability of character recognition is nevertheless implicit in other themes such as sentence structures:

It (IWB) helps you because, like, Chinese, the characters are very important, if you don't know how to recognise the characters you cannot say we are learning Chinese. (student 3)

She'll have random characters and we'll have to put them in the right order, like one to eight or whatever, so that really helps. (student 7)

An unexpected finding was students' perception of the creativity in language use afforded by the IWB. Douglas Brown (2007) notes that the goal of language learning is to be able to comprehend and produce language in unrehearsed situations. This appears to be an outcome of IWB learning:

When I open up the picture, and I see the horse... you need to be creative, and using my own words, which encourages us to be creative and come up with correct sentence structures. (student 9)

Because it is unknown it adds an element of surprise and you can't prepare beforehand and it is really more like a lifelike situation and therefore it gives you the initiative, it forces you to improvise. (student 5)

In sum, the findings from the qualitative data feedback indicate that this group of students perceive the IWB to be an effective learning tool in Chinese. The visual, interactive and participatory nature of the activities stimulate intellectual engagement and their recall of the characters. These elements contribute to perception of effectiveness afforded by the IWB learning activities.

We note also some difference in feedback from the quantitative and qualitative data. The quantitative feedback has provided the teacher with precise information about salient preferences and priorities, from a range of options supplied. The qualitative feedback however was useful to fill out a more nuanced range of student expression and enables students to offer original perceptions which have not been canvassed in the survey instrument. The pedagogical value of these complementary sources of feedback is clear, for the teacher's critical reflection on the effectiveness of her teaching. This study demonstrates the need for different types of feedback to inform development of better practice.

\section{Concluding remarks}

The focus of this feedback project was to investigate the effectiveness of IWB in learning Chinese in the tertiary language education context. Two strong themes emerged from the analysis of the data. The first was students' perception of the importance of IWB ability to facilitate interaction and participation, personal engagement and enhanced motivation. Participation, physical movement and learner exposure in the classroom are seen as positive factors in motivation and student responsibility for learning. The study underlines tertiary students' appetite for and enthusiastic response to innovative teaching.

The second theme highlighted was that the IWB is not just 'kid's stuff', a tool for the school sector, but that tertiary students also embrace its learning capabilities and identify its overall effectiveness in enhancing their acquisition of Chinese. In particular, they identified its role in their effective memorization and recognition of Chinese characters. This thus serves as important confirmation of the teacher's purposeful design of IWB visual recall activities.

Although this study has delivered important findings to one teacher in one teaching/learning context, it has wider implications for teaching and learning in many contexts. It highlights the role of the student feedback process itself. It demonstrates that the feedback process delivers important understandings of student needs and perceptions of effective learning. The process also engages both teacher and students in metacognition as it increases their critical awareness of their own teaching and learning strategies respectively. On the part of students, this has also been shown to be critical in enhancing motivation, engagement and deeper learning (Hartman, 2001; Hacker \& Graesser, 2008).

The use of the feedback will also enable the teacher to further develop her pedagogical practice, through 
implementation of the research feedback findings. For example, it will enable the teacher to give greater prominence to the inclusion of participatory interactive activities in every lesson; to continue to refine and extend the range of her IWB activities across a broader range of language skills, beyond her existing emphasis on character recognition. We have noted above that students do not perceive IWB to be as effective in supporting listening and speaking skills. In response to the feedback the teacher will explore IWB affordance to design activities to support more effective acquisition in these areas. At the end of future teaching semesters, the teacher plans to conduct a further feedback evaluation of her implementation of the new strategies which have arisen from the findings of this study.

\section{References}

Asmawi, R. (2005). Interactive whiteboard: a new dimension in Teaching and Learning. MasalahPendidikanJilid, 27: 213-219.

Beeland, W. (2002). Student engagement, visual learning and technology: Can interactive whiteboards help? Annual Conference of the Association of Information Technology for Teacher Education. Trinity College, Dublin.

Betcher, C. \& Lee, M. (2009). The Interactive Whiteboard Revolution: Teaching with IWBs. Melbourne: ACER Press.

Biggs, J. B. (1989). Approaches to enhancement of tertiary teaching. Higher Education Research and Development, Vol. 8, (1), 7-25. http://dx.doi.org/10.1080/0729436890080102

Biggs, J. B. (1999). Teaching for quality learning at university. Buckingham: Open University Press.

Digregorio, P., \& Sobel-Lojeski, K. (2009). The effects of interactive whiteboards (IWBs) on student performance and learning: a literature review. Educational Technology Systems, Vol. 38, (3), 255-312. http://dx.doi.org/10.2190/ET.38.3.b

Dornyei, Z., \& Ushioda, E. (Eds.) (2009). Motivation Language Identity and the L2 Self. Bristol: Multilingual Matters.

Douglas Brown, H. (2007). Teaching by Principles: an interactive approach to language pedagogy. San Francisco: Pearson Longman.

Glover, D. \& Miller, D. (2001). Running with technology: the pedagogic impact of the large-scale introduction of interactive whiteboards in one secondary school. Journal of Information Technology for Teacher Education, Vol. 10, (3), 257-275. http://dx.doi.org/10.1080/14759390100200115

Glover, D. \& Miller, D. (2002). The introduction of interactive whiteboards into schools in the UK: Leaders, led and the management of pedagogic and technological change. International Electronic Journal of Leadership in Learning (IEJLL), Vol. 6, (24).

Glover, D. Miller, D., Averis, D., \& Door, V. (2005). The interactive whiteboard: a literature survey. Technology, Pedagogy and Education, Vol. 14, (2), 155-169. http://dx.doi.org/10.1080/14759390500200199

Gray, C., Hagger-Vaughan, L., Pilkington, R. \& Tomkins, S. (2005). The pros and cons of interactive whiteboards in relation to the key Stage 3 strategy and framework. Language Learning Journal, 32: 38-44. http://dx.doi.org/10.1080/09571730585200171

Hacker, D.J. \& Graesser, A.C. (2008). Handbook of Metacognition in Education. Mahwah, NJ: Erlbaum/Taylor $\&$ Francis.

Hartman, H. J. (2001). Metacognition in learning and instruction: theory, research and practice. Boston: Kluwer Academic/Springer.

Hennessy, S., Deaney, R., Ruthven, K. \& Winterbottom, M. (2007). Pedagogical strategies for using the interactive whiteboard to foster learning participation in school science. Learning, Media and Technology, Vol. 32, (3), 283-301. http://dx.doi.org/10.1080/17439880701511131

Higgins, S., Beauchamp, G. \& Miller, D. (2007). Reviewing the literature on interactive whiteboards. Learning, Media and Technology, Vol. 32, (3), 213-225. http://dx.doi.org/10.1080/17439880701511040

Hodge, S. \& Anderson, B. (2007). Teaching and learning with an interactive whiteboard: A teacher's journey. Learning, Media and Technology, Vol. 32, (3), 271-282. http://dx.doi.org/10.1080/17439880701511123

Hubbard, P. \& Levy, M. (2006). Communities of practice for pre-and in-service teacher education. In, P. Hubbard $\&$ M. Levy (Eds.) Teacher education in CALL. Amsterdam: John Benjamins.

Kennewell, S., Tanner, H., Jones, S., \& Beauchamp, G. (2008). Analysing the use of interactive technology to 
implement interactive teaching. Journal of Computer Assisted Learning, Vol. 24, (1), 61-73. http://dx.doi.org/10.1111/j.1365-2729.2007.00244.x

Kramsch, C. (1993). Context and Culture in language teaching. Oxford: Oxford University Press.

Lewin C., Somekh, B., \& Steadman, S. (2008). Embedding interactive whiteboards in teaching and learning: the process of change in pedagogic practice. Journal of Education, Information, Technology, Vol. 13, 291-303.

Loughran, J.J. (2002). Effective Reflective Practice: In Search of Meaning in Learning about Teaching. Journal of Teacher Education, Vol. 53, (3), 33-43. http://dx.doi.org/10.1177/0022487102053001004

Mc Niff J., Lomax, P. \& Whitehead, J. (2003). You and Your Action Research Project. London, Routledge.

Orr, M. (2008). Learner Perceptions of Interactive whiteboards in EFL classrooms. CALL-EJ Online, Vol. 9, (2).

Orton, J. (2008). Chinese Language Education in Australian Schools. Melbourne: University of Melbourne. Confucius Institute.

Oxford, R.L. (1997). Cooperative learning, collaborative learning, and interaction: Three communicative strands in the language classroom. Modern language journal, Vol. 81, (4), 443-456. http://dx.doi.org/10.2307/328888

Pang, F. (2008). Teaching Languages with Interactive Whiteboards. Proceedings of Workshop, Chinese Language Teachers Association.

Pang, F. (2009). Fourteen ways to inspire your students in a Language classroom. Proceedings of Chinese Language Teachers Conference, NSW Department of Education and Training. Sydney, NSW.

Radloff, A., \& Samson, J. (1988). Promoting intelligent behavior in students: the role of the tertiary teacher. Paper presented at Seminar on Intelligence. Australian Council for Educational Research, Melbourne 24-26 August.

Richards J.C., \& Farrell, T.S.C. (2005). Professional Development for Language Teachers. Cambridge: Cambridge University Press. http://dx.doi.org/10.1017/CBO9780511667237

Ryan, G.W. \& Bernard, H.R. (2000). Data Management and Analysis Methods. Handbook of Qualitative Research. Edited by N. K.Denzin. \& Y. S. Lincoln, pp. 769-802. Thousand Oaks, CA: Sage Publications.

Scarino, A. \& Liddicoat, A.J. (2009). Teaching and Learning Languages: A Guide. Commonwealth of Australia.

Schmid, E. C. (2006). Investigating the use of interactive whiteboard technology in English language classroom through the lens of critical theory of technology. Computer Assisted Language Learning, Vol. 19 (1), 47-62. http://dx.doi.org/10.1080/09588220600804012

Schmid, E. C. (2008). Potential pedagogical benefits and drawbacks of multimedia use in the English language classroom equipped with interactive whiteboard technology. Computers \& Education, Vol. 51, 1553-1568. http://dx.doi.org/10.1016/j.compedu.2008.02.005

Schroeder, R. (2007). Active learning with interactive whiteboards. Communications in Information Literacy, Vol. $1,(2), 64-73$.

Smith, F., Hardman, F. \& Higgins, S. (2006). The impact of interactive whiteboards on teacher-pupil interaction in the National Literacy and Numeracy Strategies. British Educational Research Journal, Vol. 32, (3), 443-457. http://dx.doi.org/10.1080/01411920600635452

Somekh, B. (1995). The contribution of action research to development in social endeavours: a position paper on action research methodology. British Educational Research Journal, Vol. 21 (3), 339-355. http://dx.doi.org/10.1080/0141192950210307

Tanner, H., Jones, S., Kennewell, S. \& Beauchamp, G. (2005). Interactive whole class teaching and interactive white boards. MERGA 28, Melbourne, Australia. [Online] Available: http://www.merga.net.au/documents/RP832005.pdf (June $1^{\text {st }}$, 2011)

Tozcu, A. (2008). The use of interactive whiteboards in teaching non-roman scripts. Computer Assisted Language Learning, Vol. 21, (2), 143-166. http://dx.doi.org/10.1080/09588220801943726

Wall, K., Higgins, S., \& Smith, H. (2005). The visual helps me understand the complicated things': pupil views of teaching and learning with interactive whiteboards. British Journal of Educational Technology, Vol. 36, (5), 851-867. http://dx.doi.org/10.1111/j.1467-8535.2005.00508.x

Weimer, M. (2001). The influence of Technology such as a SMART Board Interactive whiteboard on student motivation in the classroom. Smarter Kids Foundation. [Online] Available: 
http://smarterkids.org/research/paper7.asp (Aug 12 $\left.2^{\text {th }}, 2011\right)$

White, K. (2007). Interactive Whiteboard Trial, South Western Sydney Region: a report. New South Wales Department of Education and Training, Centre for Learning Innovation. [Online] Available: http://www.cli.nsw.edu.au/cli/files/interactive_whiteboard_trial_easiteach.pdf (Aug 20th, 2011)

Xu, H.L. \& Moloney, R. (2011). Perceptions of IWB pedagogy in the teaching of Chinese. Australasian Journal of Educational Technology, Vol. 27, (2), 307-325.

Table 1. Student survey data Likert scale 1-5 response to statements $(\mathrm{N}=44)$

\begin{tabular}{|l|l|r|r|r|r|}
\hline \multicolumn{2}{|c|}{ The IWB } & Min & Max & Mean & $\begin{array}{r}\text { Standard } \\
\text { deviation }\end{array}$ \\
\hline 1 & increases motivation & 2 & 5 & 3.64 & .718 \\
\hline 2 & makes learning more interesting & 3 & 5 & 4.05 & .680 \\
\hline 3 & encourages active participation and interaction & 2 & 5 & 4.43 & .703 \\
\hline 4 & helps me remember vocabulary better & 1 & 5 & 3.69 & .811 \\
\hline 5 & helps me speak with good accent & 1 & 5 & 2.74 & .828 \\
\hline 6 & improves my listening & 1 & 4 & 3.10 & .850 \\
\hline 7 & improves fluency & 1 & 5 & 3.24 & .878 \\
\hline 8 & helps me remember the characters & 3 & 5 & 4.21 & .682 \\
\hline 9 & helps me write characters better & 1 & 5 & 3.60 & .964 \\
\hline 10 & helps me study for exams & 2 & 4 & 3.16 & .721 \\
\hline 11 & connection to multimedia helps me retain what I learned & 2 & 4 & 3.56 & .629 \\
\hline 12 & allows the presentation of a wider variety of information & 2 & 5 & 3.81 & .664 \\
\hline 13 & helps me grasp ideas and concepts due to a wider variety of & 2 & 5 & 3.79 & .709 \\
\hline 14 & information & 2 & 5 & 3.72 & .734 \\
\hline 15 & is especially good for learning vocabulary & 2 & 5 & 4.26 & .767 \\
\hline 16 & is good for teaching\&learning languages & 2 & 5 & 3.95 & .785 \\
\hline 17 & is not as good as traditional textbooks and whiteboards & 1 & 5 & 2.42 & .932 \\
\hline 18 & is used too much & 1 & 5 & 2.16 & 1.022 \\
\hline 19 & can be boring sometimes & 1 & 5 & 2.40 & .955 \\
\hline 20 & is not good for teaching some activities & 5 & 2.84 & .998 \\
\hline
\end{tabular}


Table 2. Number of students who mentioned items in thematic code areas $(n=11)$

\begin{tabular}{|l|l|l|l|}
\hline & Themes & $\begin{array}{l}\text { Number of } \\
\text { students }\end{array}$ & $\%$ \\
\hline 1 & Maintains engagement & 8 & 72.7 \\
\hline 2 & Physical movement: coming to the front of the class is motivating & 8 & 72.7 \\
\hline 3 & Visual display is helpful & 5 & 45.5 \\
\hline 4 & Interaction, games are good & 5 & 45.5 \\
\hline 5 & Helps with sentence structures & 4 & 36.4 \\
\hline 6 & Reinforces characters, stroke order & 3 & 27.3 \\
\hline 7 & Improves speaking, pronunciation & 1 & 9 \\
\hline 8 & Wastes time & 1 & 9 \\
\hline 9 & Makes me creative in language use & 2 & 18 \\
\hline
\end{tabular}

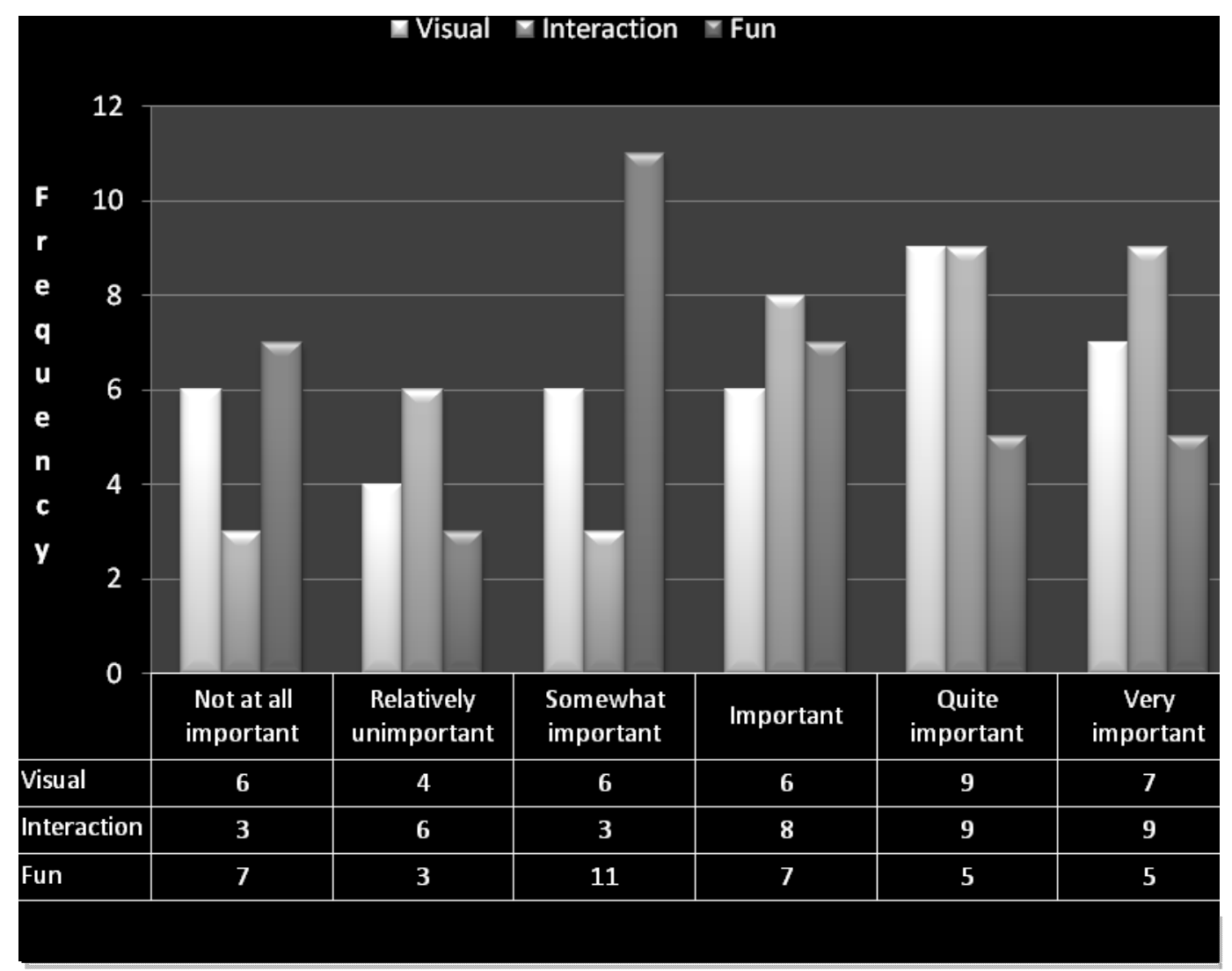

Figure 1. Visual, interaction and fun rankings $(\mathrm{N}=38)$ 


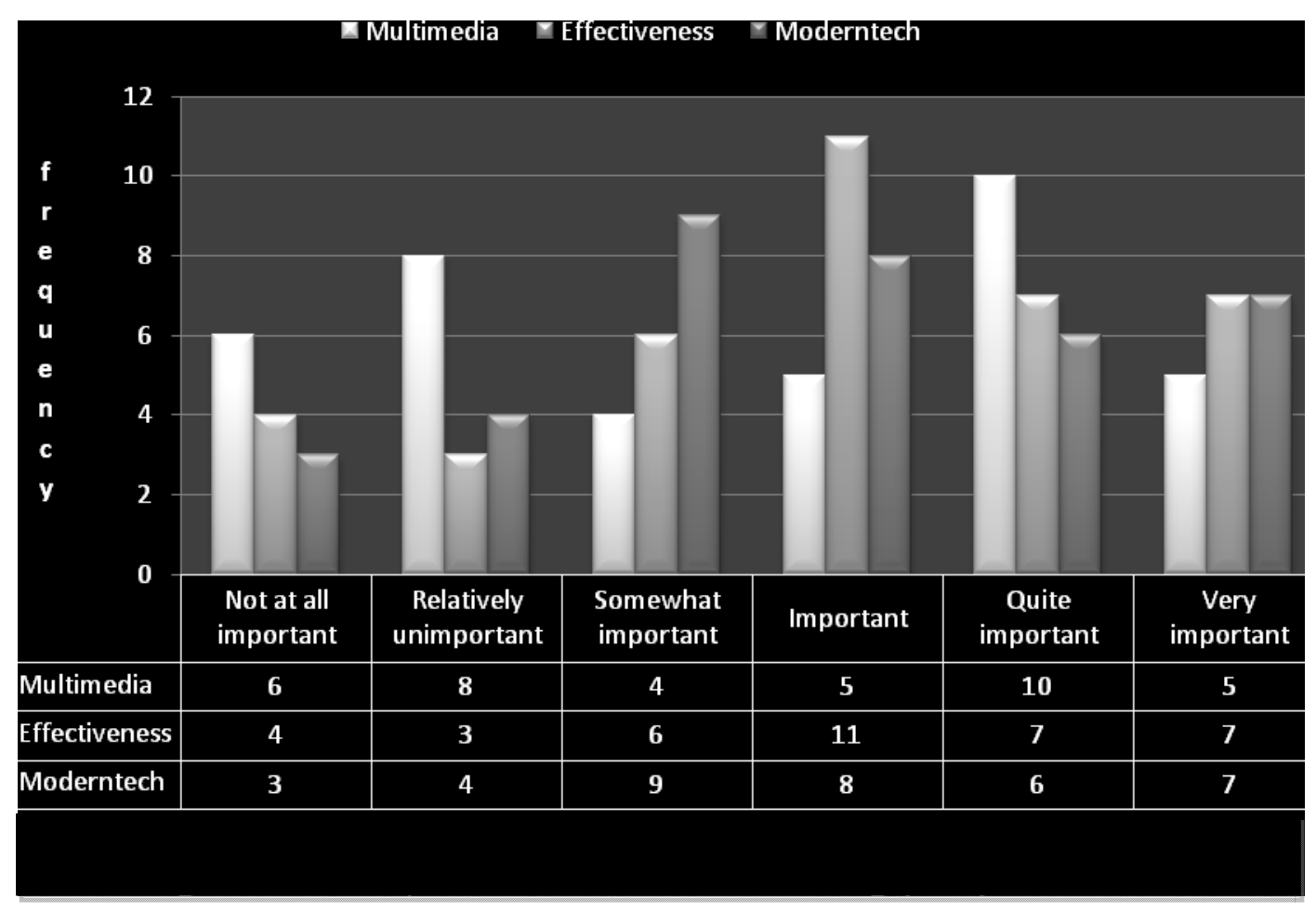

Figure 2. Multimedia, effectiveness and moderntech rankings $(\mathrm{N}=38)$

\section{Appendix 1. Student survey questionnaire}

\section{Survey Questions}

Please think about the twenty two statements below and place a tick in the column 1-5. Please indicate with the scale 1-5 whether you

1 strongly disagree with the statement

2. somewhat disagree with the statement

3. feel neutral about the statement or don't know

4. agree with the statement

5. strongly agree with the statement.

Question One "The IWB increases my motivation and interest in Chinese."

Strongly disagree $\quad$ Somewhat disagree $\quad$ Feel neutral or don't know $\quad$ Agree $\quad$ Strongly agree

$$
1
$$

3

4

5

Question Two "IWB makes content and learning more interesting."

Strongly disagree $\quad$ Somewhat disagree $\quad$ Feel neutral or don't know $\quad$ Agree $\quad$ Strongly agree 
Question Three "IWB encourages more active participation and interaction." Strongly disagree $\quad$ Somewhat disagree $\quad$ Feel neutral or don't know

Agree Strongly agree

1 2

3

4 5

Question Four "IWB helps me remember the vocabulary better."

Strongly disagree

Somewhat disagree

Feel neutral or don't know

3

Question Five "IWB helps me speak with good accent"

Strongly disagree

Somewhat disagree

Feel neutral or don't know

3

Agree Strongly agree

$$
1
$$

2

Question Six "IWB improves my listening skills."

Strongly disagree Somewhat disagree $\quad$ Feel neutral or don't know

123

3

Question Seven "IWB helps me speak Chinese more fluently."

Strongly disagree $\quad$ Somewhat disagree $\quad$ Feel neutral or don't know

1

2

3

Agree Strongly agree

4 5

Question Eight "IWB helps me remember the characters."

Strongly disagree $\quad$ Somewhat disagree $\quad$ Feel neutral or don't know
1

2

3

Question Nine "IWB helps me write characters better."

Strongly disagree $\quad$ Somewhat disagree $\quad$ Feel neutral or don't know

3

Agree Strongly agree

45

Agree Strongly agree

4

Question Ten "I have good materials from IWB lessons to study with for my exams."

Strongly disagree $\quad$ Somewhat disagree $\quad$ Feel neutral or don't know Agree Strongly agree
1
2
3
4
5

Question Eleven “The multimedia, multi modal feature of IWB help me retain what I learn.” 
Strongly disagree $\quad$ Somewhat disagree $\quad$ Feel neutral or don't know $\quad$ Agree $\quad$ Strongly agree

$\begin{array}{lllll}1 & 2 & 3 & 4 & 5\end{array}$

Question Twelve "IWB allows the presentation of a wider variety of information."

Strongly disagree $\quad$ Somewhat disagree $\quad$ Feel neutral or don't know $\quad$ Agree $\quad$ Strongly agree
1
2
3
4
5

Question Thirteen "The wider variety of information presented using IWB makes ideas and concepts easier to 'grasp'."

Strongly disagree Somewhat disagree $\quad$ Feel neutral or don't know $\quad$ Agree $\quad$ Strongly agree

$\begin{array}{lllll}1 & 2 & 3 & 4 & 5\end{array}$

Question Fourteen "I think IWB is especially good for learning vocabulary"

Strongly disagree $\quad$ Somewhat disagree $\quad$ Feel neutral or don’t know $\quad$ Agree $\quad$ Strongly agree
1
2
3
4
5

Question Fifteen "I think IWB is especially good for recognition of characters."

Strongly disagree $\quad$ Somewhat disagree $\quad$ Feel neutral or don't know $\quad$ Agree $\quad$ Strongly agree

1

2

4

5

Question Sixteen "IWB is good for teaching and learning languages."

Strongly disagree $\quad$ Somewhat disagree $\quad$ Feel neutral or don’t know $\quad$ Agree $\quad$ Strongly agree
1
2
3
4
5

Question Seventeen "I would prefer 'traditional' learning with textbooks and ordinary whiteboard."

Strongly disagree $\quad$ Somewhat disagree $\quad$ Feel neutral or don’t know $\quad$ Agree $\quad$ Strongly agree
1
2
3
4
5

Question Eighteen "I think we use the IWB too much, I get sick of it."

Strongly disagree $\quad$ Somewhat disagree $\quad$ Feel neutral or don’t know $\quad$ Agree $\quad$ Strongly agree
1
2
3
4
5

Question Nineteen "IWB can be boring sometimes."

Strongly disagree Somewhat disagree $\quad$ Feel neutral or don't know $\quad$ Agree $\quad$ Strongly agree 
Question Twenty "Some activities could be done better without the IWB."

Strongly disagree $\quad$ Somewhat disagree $\quad$ Feel neutral or don't know

Agree Strongly agree

1

2

3

4

5

2. Please rank these 6 aspects of Interactive WhiteBoard use, in your opinion, from least important (1) to most important (6). Please place a number 1 to 6, beside each statement.

It produces more interaction

It is part of a multimedia approach

It is effective in presenting language content and activities

It is fun and game-like

It is visual

It is good to have modern technology in language learning.

Thank you very much for doing our survey! 